\title{
Phytoplankton in Polishing Ponds in the Post Treatment of Anaerobic Reactor Effluent
}

\author{
Albuquerque MVC1*, Pontes TG$^{2}$, Silva MCCP1, Leite VD³, Ceballos \\ $\mathrm{BSO}^{3}$, Sousa $\mathrm{JT}^{3}$ and Lopes WS 3 \\ ${ }^{1}$ Biologist, Master in Environmental Science and Technology, Brazil \\ ${ }^{2}$ Technologist Sugarcane Production, Master in Environmental Science and \\ Technology, Brazil \\ ${ }^{3}$ Department of Sanitary and Environmental Engineering, Brazil
}

\section{Research Article \\ Volume 1 Issue 2}

Received Date: November 08, 2018

Published Date: November 20, 2018

DOI: $10.23880 /$ oajwx-16000111

${ }^{*}$ Correspomding author: Maria Virgínia da Conceição Albuquerque, Biologist, Master in Environmental Science and Technology (UEPB) Street Juvêncio Arruda, S/N, Neighborhood: Universitário, Campina Grande-PB, Center for Science and Technology-CCT-UEPB, Zip Code: 58109-790- $\quad$ Brazil, $\quad$ Tel: $55 \quad 83$ 99935-0593; Email: virginia.albuquerque@yahoo.com.br

\begin{abstract}
Considering the variable a indicative of the trophic state of aquatic environments and a useful tool in the evaluation of the impact of organic and inorganic contaminants, this work aimed to verify the occurrence and frequency of the phytoplankton community in continuous and semi-continuousflow polishing lagoons used in post-treatment of effluents from anaerobic reactors. The research was carried out at the Experimental Station of Biological Treatment of Sanitary Sewers (EXTRABES). The system consisted of an Upflow Anaerobic Sludge Blanket (UASB), an equalization tank and the transshipment pond responsible for feeding the four ponds. There were identified twenty-five taxa distribuited in five taxonomic classes: cyanobacteria (7 taxa), Chlorophyceae (5 taxa), Bacillariophyceae (4 taxa), Euglenophyceae (2 taxa) and Zygnemaphyceae ( 2 taxa). The predominance of Chlorophyceae was observed, which was constant in the four lagoons of the system, followed by Cyanobacteria, Euglenophyceae, Bacillariophyceae and Zignemaphyceae. Based on the composition of the species of cyanobacteria that were found, they present histories in the production of metabolites and are described in the literature as the producers of toxins harmful to humans and to the environment.
\end{abstract}

Keywords: Stabilization Ponds; Microalgae; Cyanobacteria

\section{Introduction}

Polishing ponds is the term used for the efluente aftertreatment units from UASB reactors since these still have the additional function of removing organic matter. These ponds can be dimensioned as maturation ponds due to high DBO removal that occurs in the anaerobic reactors. Because they are designed with low depths, 
photosynthetic activity is intense, which makes them more efficient at removing pathogens and also nutrients, especially nitrogen. For the phytoplankton organisms, some conditions of the aquatic environment are essencial to ensuretheir viability [1]. The characteristics of these communities in polishing lagoons depend on some factors such as the light penetration, the temperature and the movement in the water column. However, optical properties, nutrient availability and temperature are important parameters because they directly impact on microorganisms and indirectly on the water viscosity.

Second basically algae control the treatment efficiency and effluent quality, so this system should be designed to optimize the concentration and diversity of species of algae present [2]. The major classes of algae found in stabilization ponds are: Cyanobacteria, Chlorophyceae, Bacillaryophyceae, Euglenophyceae and Zygnemaphyceae, varying their species in each type of lagoon and environment.

The Chlorophyceae class is characterized by the high richness of taxa in comparison to the other classes, and its occurrence is notably observed mainly in brazilian continental waters, eutrophic systems and environments with organic matter. According to the Euglenophyceae only use ammonia as a nitrogen source, therefore it is more dependent on the existence of ammonia nitrogen than organic matter, which explains the presence and frequency of these genres in the stabilization ponds treating domestic sewer, considering the high concentrations of ammonia nitrogen in this environment [3]. The cyanobacteria are tolerant to organic pollution and the main genera found in stabilization ponds are:Oscillatoria,Phormidium, Microcystis and Anabaena [4]. Thus, considered as a variable that indicates the aquatic environment trophic state and as a useful tool in assessing the impact of organic and inorganic contaminants, this study aimed to determine the occurrence and frequency of phytoplankton in polishing ponds (experimental scale) of continuous and semicontinuous flow used in post-treatment of anaerobic efluente, whose final effluent in real scale are usually discharged into the environment, affecting water bodies used as a source of water for human consumption.

\section{Material and Methods}

Study Location: The study was conducted at the Experimental Biological Sewage Treatment Station (EXTRABES), located in the city of Campina Grande / PB (07- 14 ' $22^{\prime}$ 'S and $35^{\circ} 53^{\prime} 05^{\prime}$ 'W) and monitored from January to July 2015.

Experimental System: It consisted of a UASB reactor (built in glass fiber, volume of $450 \mathrm{~L}$, hydraulic retention time (HRT) of eight hours) and four polishing ponds, two of which presenting continuous flow and two characterized by a semi-continuous system (Figure 1). The raw sewage (EB) that fed the UASB came from the the sewage system of the Water and Sewage Company of Paraíba (Cagepa) east interceptor, in Campina Grande / $\mathrm{PB}$, passing by the premises of EXTRABES and was conductedto a 1,000 liters water reservoir, with a continuous flow,through the force of gravity into the UASB reactor. This reactor's effluent was directed to an equalization tank (ET) and by gravity to continuous flow ponds ( $\mathrm{LC}_{57}$ and $\mathrm{LC}_{45}$ ) and an overflow pond (LT) with with capacity of 430 liters and TDH of 2,4 days, besides feeding the two lagoons that operated in semi-continuous systems $\left(\mathrm{LB}_{45}\right.$ and $\left.\mathrm{LB}_{57}\right)$ (Figure 1$)$.

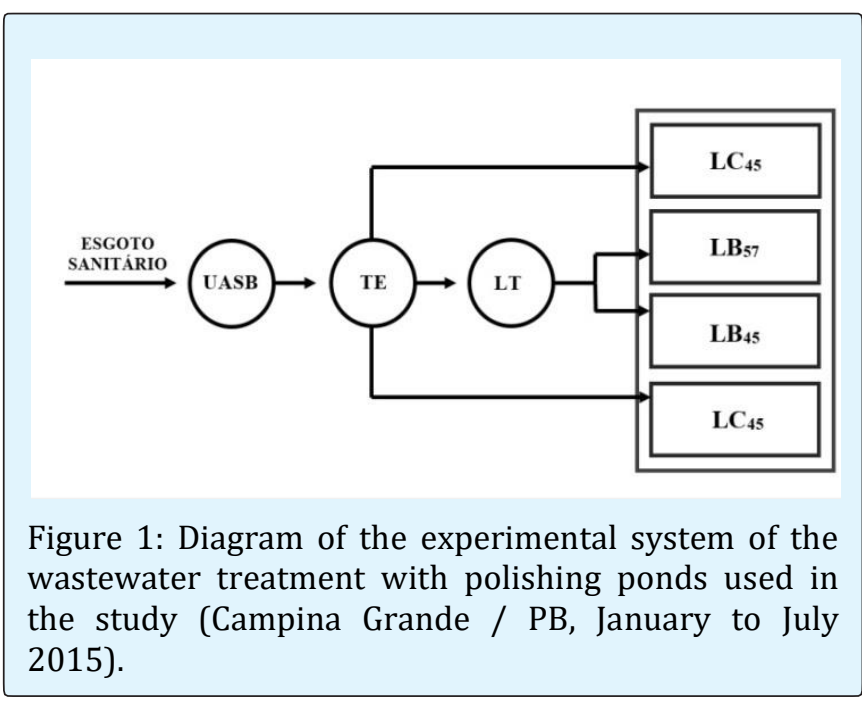

The four pools were constructed in stone masonry and its characteristics are shown in Table 1.

\begin{tabular}{|c|c|c|c|c|c|c|c|}
\hline lagoons & & Depth(cm) & Area (m & Volume (L) & TDH(days) & Flow rate (L/ day) & TAS * \\
\hline $\mathrm{LC}_{57}$ & to be continued & 57 & 2 & 1140 & 12 & 95 & 53.7 \\
\hline $\mathrm{LB}_{57}$ & semi & 57 & 1.76 & 1000 & 10 & 100 & 60.8 \\
\hline $\mathrm{LB}_{45}$ & semi & 45 & 1.76 & 792 & 10 & 79 & 48 \\
\hline $\mathrm{LC}_{45}$ & to be continued & 45 & 1.76 & 792 & 12 & 66 & 42.4 \\
\hline
\end{tabular}

Table 1. Characteristics of polishing ponds.

* TAS: Surface Application Rate (kgDQOfha-1day-1). 
For qualitative analysis of phytoplankton collections were made at three points in the horizontal plane of the ponds (beginning, middle and end) at different depths: in $\mathrm{LC}_{57}$ and $\mathrm{LB}_{57}$ algae and cyanobacteria were identified in the collected samplesat a depth of $10 \mathrm{~cm}$ and $50 \mathrm{~cm}$ and in $\mathrm{LB}_{45} \mathrm{LC}_{45}$ at a depth of $10 \mathrm{~cm}$ and $40 \mathrm{~cm}$. For this, PVC column collectors were used, which were perfectly cleaned and introduced closed and open in each of the selected depths measured in a graduated rule in the tube. The samples were stored in new 500ml PET bottle covered with aluminum foil to avoid exposure to light. To each bottle was added $4 \mathrm{ml}$ of Lugol's solution $\left(\mathrm{I}_{2}+\mathrm{KI}\right) 4 \%$ for phytoplankton preservation and thenwas peformed its idenfication. The identification was done with binocular Olympus CBA microscope, magnification $\mathrm{x}$ 400. The classification for classes and genres followed [5]. The relative abundance (A) of each taxon was calculated from the direct count of organisms and the results transformed to percentages according to Equation 1:

At where:

$$
A=\frac{N \times 100}{n}
$$

A: relative abundance.

$\mathrm{N}$ : number of identified taxa individuals.

$\mathrm{n}$ : total number of individuals in the sample.

The frequency of occurrence (F) was expressed as a percentage, taking into account the number of samples (Equation 2).

$$
F=\left(\frac{P a}{P}\right) \times 100
$$

At where:

Pa: number of samples in which the taxon occurred.

P: the total number of analyzed samples.

The frequency of occurrence of the species was evaluated based on the rating, considering constant when exceeding $50 \%$, common when it was between $10 \%$ and $50 \%$, and rare when it was up to $10 \%$ [6].

\section{Results And Discussions}

According to, the chemical composition of anaerobic sewage treatment effluent is suitable for algal growth. Nitrogen compounds are converted into ammonia, an important source of nitrogen for the micro-algae [7-10]. Another advantage for the use of anaerobic effluent to the growth of microalgae is the presence of $\mathrm{CO}_{2}$ in the form of bicarbonate, and organic acids which are used in heterotrophic/mixotrophic growth of some microalgae [11].
In the study, the phytoplankton community was composed of 20 taxa distributed in five taxonomic classes, 7 belonging to Cyanophyceae (35\%), 5 to Chlorophyceae $(25 \%), \quad 4$ to Bacillariophyceae $(20 \%), 2$ to Euglenophyceae (10\%) Zygnemaphyceae and 2 (10\%). Six of the 20 taxa were identified to species level (Cylindropermopsis raciborkii, Monoraphidium arcuatum, Monoraphidium minutum, Phacus longicauda, palea Nitzschia, and Phacus tortus)and fourteen in the genus level(Gomphonema sp, Navicula sp, Cymbella sp, Scenedesmus sp, Chlorococcum sp, Chlorella sp, Cosmarium sp sp Closterium, Phormidium sp, Lyngbya sp, Gleiterinema sp, Microcystis sp, Oscillatoria sp and Planktothrix sp). There was a predominance of Chlorophyceae, which were present in the four lagoonsof the system, followed by, Euglenophyceae,Cyanobacteria Bacillariophyceae and Zignemaphyceae.

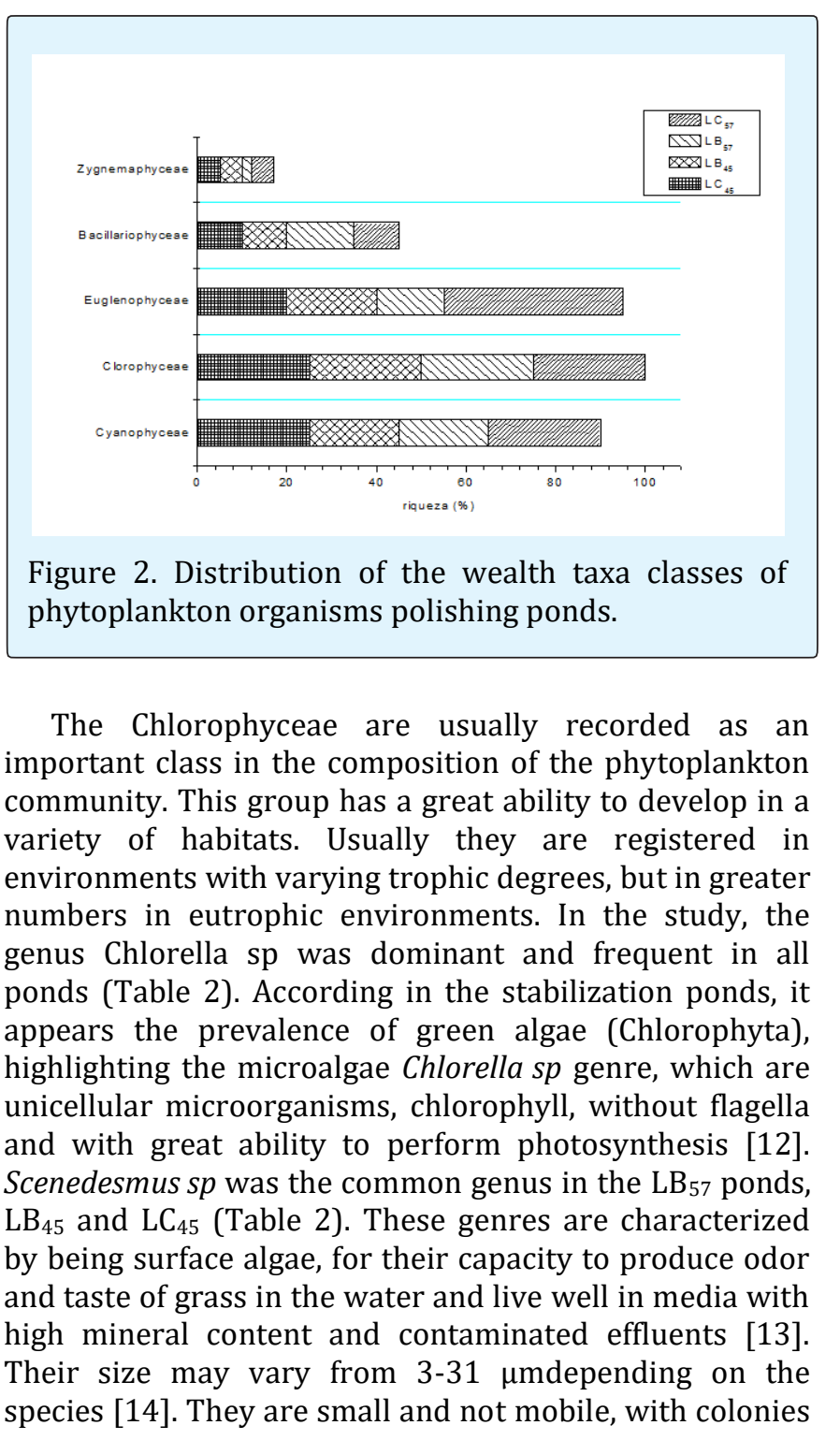


consisting of cells aligned on a flat board and its colonies are usually composed of 4-8 cells [15]. It is relevant that Chlorella and Scenedesmus exhibit high levels of carbohydrates (mainly starch). Carbohydrates from microalgae can be hydrolysed and converted into glucose, which is a significant substrate for heterotrophic microorganisms (such as yeast, bacteria and fungi) for the production of biofuels.

\begin{tabular}{|c|c|c|c|c|}
\hline Taxa & \multicolumn{4}{|c|}{ Often in ponds } \\
\hline Clorophyceae & CC $_{57}$ & LB $_{57}$ & $\mathbf{L B}_{45}$ & $\mathbf{L C}_{\mathbf{4 5}}$ \\
\hline Monoraphidium arcuatum & CT & CM & CT & CT \\
\hline Monoraphidium minutum & CT & CT & CT & CM \\
\hline Scenedesmus sp & R & CM & CM & CM \\
\hline Chlorococcum sp & CT & CT & CM & R \\
\hline Chlorella sp & CT & CT & CT & CT \\
\hline
\end{tabular}

Table 2: Composition and frequency of the observed Clorophyceae occurrence monitoring the liquid mass of the polishing ponds.

* CT: Constant; CM: Common; A: Rare; ND: Not Detected

The cyanobacteria class is resistant to pollution, waste and anaerobic environments with a high organic load. The presence of about $35 \%$ in the study may be related to high turbidity, which discriminates the group cyanobacteria, especially those fixing $\mathrm{N}_{2}$ [16]. According cyanobacteria have the ability to produce acinetos, which function as resistance spores under adverse conditions, allowing the survival of the cell for long periods; it may form gaseous vacuoles called aerobes, which enable vertical migration in the water column, and can fetch the depth at which both light intensity and the concentration of nutrients are favorable; They tolerate large variations in temperature; They are able to store phosphorus in the form of polyphosphates grains in the cytoplasm and can be toxic to other organisms [17].

The semi-continuous flow ponds showed higher frequencies of cyanobacteria, results favored by the transhipment pond (LT) by reducing total solids and subsequently reducing the effluent of these polishing ponds in a semi-continuous system. Filamentous species of cyanobacteria (Cylindropermopsis raciborkii, Phormidium sp, Lynblya sp, Gleiterinema sp, Oscillatoria $s p$ and Planktothrix $s p$ ) showed competitiveness with other phytoplankton species. For under limited conditions of nitrogen, but other nutrients available, growth and reproduction of cyanobacteria are possible, which favors the flowering of such species in different types of environments. Probably the competitive success of cyanobacteria found, especially the dominant filamentous species (Planktothrix sp) (Table 3) in relation to other species is based on physiological, ecological and adaptive strategies of the same, and strengthened due to the provision of suitable conditions for their development [18].

Planktothrix $s p$ is a species having solitary trichomes that remain in the water column. The presence of aerobes gives its buoyancy. Adapted for low light intensities, and by the high turbidity which itself can cause and suppress the growth of other phytoplankton species by limiting the entry of light through the water column [19].

\begin{tabular}{|c|c|c|c|c|}
\hline Taxa & \multicolumn{4}{|c|}{ Often in ponds } \\
\hline Cyanobacteria & LC $_{57}$ & LB $_{\mathbf{5 7}}$ & $\mathbf{L B}_{\mathbf{4}}$ & $\mathbf{L C}_{\mathbf{4 5}}$ \\
\hline Microcystis sp & CT & CM & CM & CM \\
\hline Planktothrix sp & CT & CT & CT & CT \\
\hline Oscillatoria sp & CM & CT & CM & CT \\
\hline Cylindrospermopsis raciborskii & CM & CT & CT & CM \\
\hline Phormidium sp & CM & CM & R & CM \\
\hline Gleiterinema sp & CM & CM & CM & CM \\
\hline Lyngbya sp & ND & CM & CM & R \\
\hline
\end{tabular}

Table 3: Composition and frequency of occurrence of cyanobacteria observed monitoring the liquid mass in polishing ponds.

* CT: Constant; CM: Common; A: Rare; ND: Not Detected

The Euglenophyceae class has preferencefor high levels of ammonia, being favored at high biochemical oxygen demand conditions, and with high load of organic matter and may be a biological indicator of organic pollution of water, the pigmented flagellates genres as Euglena, Lepocinclis, Phacus and Trachelomonas stand out for the presence in shallow biotopes that are rich in organic matter, such as dams, reservoirs, rivers and lakes, and stabilization ponds [20]. There was a continuous presence of the Phacus longicaudaspecies in all studied ponds (Table 4).

\begin{tabular}{|c|c|c|c|c|}
\hline Taxa & \multicolumn{4}{|c|}{ Often in ponds } \\
\hline Euglenophyceae & LC $_{57}$ & LB $_{57}$ & $\mathbf{L B}_{\mathbf{4 5}}$ & $\mathbf{L C}_{\mathbf{4 5}}$ \\
\hline Phacus longicauda & CT & CT & CT & CT \\
\hline Phacus tortus & R & CM & CT & CT \\
\hline
\end{tabular}

Table 4: Composition and frequency of occurrence of the observed Euglenophyceae monitoring the liquid mass in polishing ponds.

* CT: Constant; CM: Common; A: Rare; ND: Not Detected

According Bacillariophyceae (diatoms) respond to low phosphorus concentration giving them a competitive advantage towards the other algal groups [21]. In the study, four taxa were identified: Gomphonema sp, Navicula $s p$, Nitzschia palea and Cymbella sp (Table 5). These 
species are very sensitive to variations in the chemical composition of the liquid mass. They have as a pigment chlorophyll a, c1 and c2, carotenoids and xanthophylls and the cell wall is composed of silica [22]. However, only Niszchia paleahas been frequent in the four polishing lagoons.

\begin{tabular}{|c|c|c|c|c|}
\hline Taxa & \multicolumn{4}{|c|}{ Often in ponds } \\
\hline Baccilariophyceae & LC $_{\mathbf{5 7}}$ & $\mathbf{L B}_{\mathbf{5 7}}$ & $\mathbf{L B}_{\mathbf{4 5}}$ & $\mathbf{L C}_{\mathbf{4 5}}$ \\
\hline Gomphonema sp & $\mathrm{CM}$ & $\mathrm{R}$ & $\mathrm{R}$ & $\mathrm{R}$ \\
\hline navicula sp & $\mathrm{R}$ & $\mathrm{CM}$ & $\mathrm{CM}$ & $\mathrm{CM}$ \\
\hline Niszchia palea & $\mathrm{CM}$ & $\mathrm{CM}$ & $\mathrm{CT}$ & $\mathrm{CM}$ \\
\hline Cymbella sp & ND & ND & R & R \\
\hline
\end{tabular}

Table 5: Composition and frequency of occurrence of the observed Baccilariophyceae monitoring the liquid mass in polishing ponds.

*CT: Constant; CM: Common; A: Rare; ND: Not Detected

The division had Zignemaphyceae low diversity (20\%) and frequency of occurrence in the lakes (Table 6), mainly the ratio of representatives of this class with acidic water [23]. In turn, Cosmarium sp may occur in the clearest waters and in environments with eutrophic conditions, which is the case of polishing ponds. This genre was evidenced in $\mathrm{LC}_{57}$ as Table 6 [24].

\begin{tabular}{|c|c|c|c|c|}
\hline Taxa & \multicolumn{4}{|c|}{ Often in ponds } \\
\hline Zygnemaphyceae & $\mathbf{L C}_{\mathbf{5 7}}$ & $\mathbf{L B}_{\mathbf{5 7}}$ & $\mathbf{L B}_{\mathbf{4 5}}$ & $\mathbf{L C}_{\mathbf{4 5}}$ \\
\hline Cosmarium sp & $\mathrm{CM}$ & $\mathrm{ND}$ & $\mathrm{R}$ & $\mathrm{R}$ \\
\hline closterium sp & $\mathrm{R}$ & $\mathrm{ND}$ & $\mathrm{ND}$ & $\mathrm{ND}$ \\
\hline
\end{tabular}

Table 6: Composition and frequency of occurrence of the observed Zygnemaphyceae monitoring the liquid mass in polishing ponds.

* CT: Constant; CM: Common; A: Rare; ND: Not Detected

\section{Conclusion}

The treatment of domestic sewage in UASBs reactors followed by polishing pond is a sustainable alternative able to preserve the advantages of operational simplicity and low operating and maintenance costs. The phytoplankton community favors the environmental conditions in aquatic environments. Its ability to synthesize organic matter, rapid development, multiplication and sudden disappearance, are dynamic aspects that indicate the quality of the environment in which they are present. In addition, work on the physical and chemical conditions, changing color, turbidity, oxygenation, alkalinity and other properties of the water they inhabit.
Specifically, in sewage treatment, the phytoplankton contributes by embodying photosynthetic pigments called chlorophyll, thus produces oxygen, which corresponds to its main function in the stabilization ponds, directly influencing the realization of aerobic decomposition processes. In the study, 20 taxa were identified over five taxonomic classes: Cyanobacteria (7 taxa), Chlorophyceae (5 taxa), Bacillariophyceae (4 taxa), Euglenophyceae (2 taxa) and Zygnemaphyceae (2 taxa). There was a predominance of Chlorophyceae, which was constant in the four system ponds, followed by Cyanobacteria, Euglenophyceae, and Zignemaphyceae Bacillariophyceae.The microalgae Chlorella $s p$ was the most representative species of microalgae, while Planktrothrix sp was the dominant cyanobacteria.

Importantly, although it has not been performed cyanotoxins detection analysis, the marked presence of species of cyanobacteria during the entire period studied are described in the literature as producing toxins. The release of effluents of these ponds in the environment creates great risks to public and environmental health. Therefore, the discharge of these organisms in water bodies represents an important toxic potential of water, affecting its multiple uses.

\section{References}

1. Von Sperling M (2005) Introduction to water quality and sewage treatment, vol-1, $3^{\text {rd }}$ (Edn.), Belo Horizonte pp: 452.

2. Von Sperling M, Oliveira CM (2010) The influence of hydraulic retention time and surface application rate of the composition of the phytoplankton present in the polishing ponds and the influence of the community in environmental conditions $\mathrm{pH}, \mathrm{DO}$ and ammonia) ponds. Magazine AIDIS 3(1): 11-21.

3. Miwa ACP, Freire RHF, Calijuri MC (2007) Nitrogen Dynamics in a Stabilization Ponds System in the Ribeira Valley region (São Paulo-Brazil). Sanitary and Environmental Engineering 12(2): 169-180.

4. Soldatelli VF, Schwarzbold A (2010) Community fi toplanctônica in maturation ponds, Caxias do Sul, Rio Grande do Sul, Brazil. Iheringia Botany Series 65(1): 75-86.

5. Bicudo CEM, Menezes M (2006) Continental Water Algae Genres of Brazil-key to identification and descriptions, $2^{\text {nd }}$ (Edn.), San Carlos: Rima Publisher, pp: 502 . 
6. Wolf E, Leighton G (1986) de las Estructuras comunitarias fitocenosis planktonic de los mouths of river systems estuaries y de la central zone of Chile. Rev Biol Mar 22(1): 1-29.

7. Zhang CM, Mao ZG, Wang X, Zhang JH, Sun FB, et al. (2010) Effective ethanol production by anaerobic digestion distillage reutilizing waste effluent inan integrated Both fermentation process coupled with methane and ethanol fermentations. Bioprocess Biosyst Eng 33(9): 1067-1075.

8. Chi Z, Zheng Y, Jiang A, Chen S (2011) Lipid production by culturing oleaginous yeast and algae with food waste and municipal wastewater in an integrated process. Appl Biochem Biotechnol 165(2): 442-453.

9. Olguin EJ (2012) Dual purpose microalgae-bacteriabased systems que treat wastewater and produce biodiesel and chemical products Within the Biorefinery. Biotechnol Adv 30(5): 1031-1046.

10. Kassab G, Halalsheh M, Klapwijk A, Fayyad M, Lier VJB (2010) Sequential anaerobic-aerobic treatment for domestic wastewater-A review. Bioresource Technology 101(10): 3299-3310.

11. Larsdotter K (2006) Microalgae with Wastewater treatment-a literature review. Vatten 62: 31-38.

12. Marcon AE (2005) Removal of fecal coliforms microalgae (Chlorella) immobilized in calcium alginate matrix. Dissertation (Masters in Sanitary Engineering)-Federal University of Rio Grande do Norte.

13. Aquino EP, Oliveira ECC, Fernandes UL, Lacerda SR (2011) Phytoplankton of a stabilization pond in northeastern Brazil. Braz J Aquat Sci Technol 15 (1): 71-77.

14. Gonzalez AAC, Bicudo CEDAW (2010) Cryptogams State Park of Fontes do Ipiranga, São Paulo, SP. Algae, 30: Chlorophyceae (Scenedesmaceae family). Hoehnea: Botanical Institute, pp: 37.

15. Chaichalerm S (2012) Culture of microalgal strains isolated from natural habitats in Thailand in various enriched medium. Applied Energy 89(1): 296-302.
16. Escorihuela A, Núñez M, Rosales N, Mora R, Morales E (2007) Microalgas present in a lagoon for polishing effluents from a plant treatment of urban waste water. Rev Fac Agron (LUZ) 24(1) 225-230.

17. Sant'anna CL, Azevedo MTP, Agujaro LF, Carvalho MC, Carvalho, LR, Souza RCR (2006) Identification and cyanobacteria count of planktonic Brazilian continental waters. Interscience, Rio de Janeiro, pp: 58.

18. Dias FC, Rodrigues TE, Von Sperling MVAJ (2014) Overall performance evaluation of shallow ponds maturation in seriestreating UASB reactor effluent: Ten years of intensive monitoring of Asystem in Brazil. Ecological Engineering 71: 206-214.

19. D'aquino CA, Schroeder L (2009) Low cost system Proposal for microalgae cultivation. Academic Department of Chemistry and Biology, Federal Technological University of Paraná, Curitiba.

20. Riediger W, Bueno NC, Jati S, Sebastien NY (2014) Phytoplankton stabilization ponds Sewage Treatment Plant (WWTP) in western Parana, Brazil: hlorophyceae and Euglenophyceae classes. Iheringia Botany Series 69(2): 329-340.

21. Vercellino LS (2001) Succession of periphyton in two reservoirs of Ipiranga Parque das Fontes. Sao PauloSP, UNESP.

22. Fernandes H (2009) The dynamics of the biota in a system of shallow stabilization ponds for treatment of landfill leachate. Florianópolis - SC. 186f, Dissertation (Masters in Environmental Engineering). Federal University of Santa Catarina.

23. Coesel PFM, Krienitz L (2008) Diversity and geographic distribution of desmids and other coccoid green algae. Biodiversity and Conservation 17: 381392.

24. Bicudo CEM, Ungaretti I (1986) Desmids (Zignemaphyceae) lagoon-Dam Waters Fine, Rio Grande do Sul, Brazil. Brazilian Journal of Biology 46: 285-307. 